\title{
A Tentative Analysis of Gary Snyder's Attitudes towards Chinese Culture in his Translation of Chinese Poems
}

\author{
Ying $\mathrm{Wu}$ \\ Zhenjiang Watercraft College of PLA, Zhenjiang, Jiangsu, 212003, China \\ Email: wycherry@sina.com \\ Qi Pan \\ Zhenjiang Watercraft College of PLA, Zhenjiang, Jiangsu, 212003, China
}

\begin{abstract}
Gray Snyder was a famous poem translator and writer in America in the 20th century; however, his translation and composition were deeply influenced by the ancient Chinese culture, especially by Han Shan, the famous hermit and poet of the Tang Dynasty. This article attempts to make a tentative analysis of Snyder's translation of Chinese poems as well as his attitudes towards Chinese culture and Chinese poems.
\end{abstract}

Index Terms - Gary Snyder, Han Shan, translation, poem, Chinese culture

\section{BRIEF INTRODUCTION OF GARY SNYDER AND HAN SHAN}

\section{A. Gary Snyder}

Gary Snyder was born in 1930 in San Francisco. He had begun to write mature poems in a form of his own at the age of 25. Since the 1960s, his work has been increasingly analyzed and praised by critics. In 1975 he won the Pulitzer Prize for Turtle Island (published in 1974), and in 1987 he was elected to the American Academy and Institute of Arts and Letters. In addition to his poetry, he has a large quantity of publications, including several volumes of prose and essays in various environmental magazines (McNeil, 1983). As a result, he has been recognized not only as one of the most important contemporary poets alive today, but also a thinker, an important spokesperson for American Buddhism, international ecological movement, and bioregional philosophy.

\section{B. Han Shan}

Han Shan was a hermit and poet of the Tang Dynasty (618-906). Little is known about all of Han Shan's life, and he is somewhat of a legendary character. According to Red Pine, Chinese scholar and Cold Mountain translator, Han Shan was born into some level of privilege and may have been a gentleman farmer and some sort of minor official in imperial China. At some point he was married. Eventually he became disaffected with society and left the world at 30 to make his home in the Tian-Tai Mountains.

\section{Background and Influence of Snyder's Translation of Han Shan's Poems}

Snyder got in touch with Chinese culture at an early age. From the age of ten, he began to see East Asian landscape paintings at the Seattle Art Museum. He recalled in an interview in 1977 that when he first saw Chinese landscape paintings, 'they blew my mind'. In 1947 when he was 17 years old, he entered Reed College where he began to read Ernest Fenollosa's Epochs of Chinese and Japanese Art, Ezra Pound's and Arthur Waley's translations of Chinese poetry, a translation of the Tao Te Ching, and some texts of Confucius. After graduation from Reed with BA in anthropology and literature, Snyder worked as a timber scaler on Warm Spring Indian Reservation, and in autumn of the same year, he began a graduate program in anthropology at Indiana University. However, he soon left the university and spent the summer on top of Crater Mountain, where he studied Chinese and prepared to translate Chinese poetry. $\mathrm{He}$ isolated himself and concentrated on learning Chinese, enjoying the maximum pleasure in translating Chinese poetry. In the fall of 1955, Snyder enrolled in a graduate seminar in Chinese poetry with Chen Shi-xiang. This was Snyder's introduction to Han San, the legendary hermit-poet. Arthur Waley was the first Western scholar to translate the poems of Han Shan. In 1954, he published a translation of twenty-seven of the poems in Encounter. Gary Snyder's "Cold Mountain Poems" appeared in 1958 in Evergreen Review with twenty-four pieces. Burton Watson published his translation of 100 poems in 1962.

Snyder's translations of Han Shan's poems had the greatest influence, though not the most in quantity, in the United States. They soon become popular especially among the college students, the 'Beat Generation' as they were called. Thus Han Shan appears together with the greatest writers of Chinese literature such as Li Bai, Wang Wei, and Du Fu, and has enjoyed a prestige he never attained in the past. In Jack Kerouac's novel The Dharma Bums, Gary Snyder as a 
hero was also called American Han Shan (Jack Kerouac, 1958). What's more, in 1999, Charles Frazier's work Cold Mountain (Charles Frazier, 1997) got the American Book Award. There is such a sentence on the first page of the book, 'People ask the way to Cold Mountain. Cold Mountain? There is no road that goes through'. This is actually a translation of Han Shan's poem '人问寒山道, 寒山路不通'. The influence of Han Shan and his poems in the United States can be seen clearly here.

\section{APPRECIATION AND ANALYSIS ON SNYDER'S POEM TRANSLATION}

Compared with other translators of Han Shan's poems such as Arthur Waley and Burton Watson, Snyder's translation has some special features that make it popular and well-accepted. Snyder once talked about his translation in a letter to Herbert Fackler. In this letter, he said that 'My translations were done as work in a graduate seminar at Berkeley (where I studied 3 years in the graduate school of the Department of Oriental Languages) under Professor Chen Shi-xiang. They are completely accurate line-for-line translations. There are a few substitutions, i.e. "silverware and cars" for equivalent but culture-bound symbols of affluence in the Tang dynasty; the "colloquial" tone is justified by the fact that Han Shan is writing in the colloquial of his own period, with a rough and slangy tone in spots. ' (Leed, 1986)

From his own words we can conclude at least three characteristics about the style of Snyder's translation. The first is 'accurate line-for-line' translation. The second is the application of some modern images to substitute the ancient symbols of Tang dynasty. The last but not least is the widely-used colloquial tone in his works. The following are some detailed analysis on these three features with examples from his translation.

\section{A. The 'Accurate line-for-line' Translation - Foreignization}

Such a method is actually quite dangerous in poem's translation, as most people may consider it beyond understanding. For example, in the poem of Han Shan we mentioned just now, there is a sentence '入塞红尘起'. To our surprise, Snyder just translated ‘红尘' as 'red dust'. What's more, in the fifth poem, he translated ‘下有斑白人, 喃喃 读黄老' as 'Under it a gray-haired man, Mumbles along reading Huang and Lao'. And still, he translated “黄泉' in '大 半入黄泉' of the tenth poem as 'the Yellow Springs'. We believe that most English native speakers do not know what 'red dust', 'Huang and Lao' or 'Yellow Springs' stand for. To them, this kind of translation does not translate anything at all. Then, why did Snyder take such an extreme foreignization method? And why these works were still well-accepted instead of refused by the American society? To explain these questions, we need first look at the social conditions of the US at that time.

It is well known that the American economy and industry had a rapid development after the Second World War. However, many social problems of modern world also emerged and became gradually serious under the compression of industrialization. Snyder once pointed out that the whole western culture might have stepped into a wrong direction, not just the capitalism, and that there was a sign of self-destruction in American culture. At that time, large numbers of American youth became dissatisfied and doubtful about their own culture and religion. They were looking for a new belief to support themselves. The image of Han Shan and his poems, as well as the Zen Buddhism just met their requirement to some extent and therefore soon got popular in America in those years. In such an environment, a sense of foreign cultures and foreign customs in concepts and images was just what people needed to refresh the American culture and American literature. The ideas and philosophy in Han Shan's poems, as well as his life style, like fresh air, were welcome and imitated by lots of American youth. Those foreignized words and phrases in Snyder's translation just provided them with a new bank of expressions to show off and make themselves different. Therefore, Snyder's application of foreignization method in his translation can better be explained as intended and successful practices than careless mistakes.

\section{B. The Involvement of TL Images in Translation - Domestication}

Just as Snyder himself has mentioned, in his translation there are a few substitutions for equivalent but culture-bound symbols of affluence in the Tang dynasty, such as 'silverware and cars'. This appears in his translation of the following sentence “寄语钟鼎家，虚名定无益。' as 'Go tell families with silverware and cars “What's the use of all that noise and money?”, Here he made use of the image of 'silverware and cars' to replace “钟鼎”. ‘钟鼎” was a symbol of rich family in ancient Tang Dynasty and 'silverware and cars' also immediately remind modern people of wealth, power and prosperity. Both of these two symbols contain the same implication though in different social backgrounds and time. This is a typical domestication method as there were definitely no cars in ancient China. However, such kind of treatment doesn't take a large part in his translations and is only used to deal with those images or concepts that are not so important to convey the ideas of Zen Buddhism. From this point, we can see that, foreignization or domestication, they are just instruments employed by Snyder to meet his own requirements and purposes. We will have further discussion on this issue later.

\section{The Employment of Oral Language}

Compared with other translators' works, an outstanding feature of Snyder's translation is his colloquial tone. 


\section{人问寒山道, \\ 寒山路不通。 \\ 夏天冰未释, \\ 日出雾朦胧。 \\ 似我何由届, \\ 与君心不同。 \\ 君心若似我, \\ 还得到其中。}

Men ask the way to Cold Mountain.

Cold mountain: there's no through trail.

In summer, ice doesn't melt

The rising sun blurs in swirling fog.

How did I make it?

My heart's not the same as yours.

If your heart was like mine

You'd get it and be right here.

Translated by Gary Snyder

I Sketch a Map in a Cup of Tea

Travelers wonder how to reach Cold Mountain.

No road stretches so far; the streams end far below.

Summer ice darkens the greens.

Sunrise labors to burn off the mist.

How did a gray squat thing like me arrive?

I make my journey sitting still.

Translated by Peter Stambler

The above are two translations of Han Shan's 人问寒山道, one by Gary Snyder and the other by Peter Stambler (1996). Snyder's translation is just like an everyday dialogue without any modification. For example, the first sentence '人问寒山道, 寒山路不通。' was translated as 'Men ask the way to Cold Mountain. Cold mountain: there's no through trail'. It's so simple and direct. On the other hand, Peter Stambler's translation was 'Travelers wonder how to reach Cold Mountain. No road stretches so far; the streams end far below'. It has more sense of literature and more sense of poetry. Just as we have mentioned above, Snyder justified himself by saying that his application of colloquial tone in translation was according to the fact that 'Han Shan is writing in the colloquial of his own period, with a rough and slangy tone in spots.' (Leed, 1986). This is the truth. One of the reasons that Han Shan's poems did not enjoy a reputation as Li Bai, Du Fu, Wang Wei etc. in Tang Dynasty was that most critics at that time thought that his poems were too oral and too direct, which didn't in accordance of the aesthetical standard for poetry in ancient China. However, this colloquial style soon got popular and famous once it was transported by Snyder from the East to the West, and became a symbol of Snyder's works. We can hardly say whose translation is better, Snyder's or Stambler's, but one thing clear is that Snyder's translation is more successful and better accepted by the target language readers.

\section{Analysis on Snyder's AtTitudes towards Chinese PoEMS AND Chinese Culture.}

There's no doubt that Snyder loves, admires and enjoys Chinese poems and Chinese culture. As we have introduced before, he had a contact with Chinese culture at very early age and devoted himself to the study of Chinese culture and translation of Chinese poems lifelong. What's more, he even lived in a Chinese hermit style like Han Shan and was thus called American Han Shan. However, we can never comment on somebody or some phenomenon without any social and cultural background. Snyder and his practices, his works, as well as his attitudes towards Chinese poems and Chinese culture should all be considered in connection with the American society at that time. As we have mentioned before, in the 1950s after the World War Two, most young people in America became disappointed and tired with the rapid development of modern society. They refused the common life style and indulged themselves in a wild and crazy life. They abandoned the traditional western culture and religion and looked for a substitution from the outside world. Therefore, it's quite natural that Han Shan's poem as well as his vigorous and unrestrained life style could soon attract the young Americans. As one of them, Snyder was even more devoted than others (Parkinson, 1983).

From the very beginning, the reason of Snyder's love to Chinese poems and the purpose of his translation were very clear. It's a combination of social demand and personal emotion. His affection to Chinese culture, especially the Zen Buddhism was a rebellion to traditional western culture and religion to some extent, and his translation of Chinese poems was to introduce and spread a new literature atmosphere in the US. In this case, his attitude towards Chinese poems and culture could only be some kind of 'borrowing' and 'making use of' like what Lu Xun called '拿来主义', instead of a pure respect to Chinese culture. With such an attitude, most of his translations have a postmodern feature, and was called Cultural Colonialism by some critics. But we don't have to be so radical. Objectively speaking, Snyder's 
translation is quite successful either in its language or in the influence in the society. It does contribute a lot in popularizing Chinese culture and Chinese poems in the western world.

One important fact we haven't mentioned up till now is that Gary Snyder was not only a translator but also a poet himself. He had been greatly influenced by Ezra Pound, the leader of American Imagism. According to Pound, 'an image is that which presents as intellectual and emotional complex in an instant of time'. Though image is a new concept to western readers, it has long been a basic principle of poem creation and evaluation in Chinese culture. Ezra Pound knew this, so he studied a lot about Chinese poems and learned a lot from them. He also translated some poems, though they can hardly be recognized by the SL speakers. Snyder's poet composition also presents a strong influence by Imagism of Chinese culture. The following is one of his works:

Pine Tree Tops

In the blue night

frost haze, the sky glows

with the moon

pine tree tops

bend snow-blue, fade

into sky, frost, starlight.

The creak of boots.

Rabbit tracks, deer tracks,

what do we know.

By Gary Snyder

Read this poem and we can soon associate it with the image in one of Wang Wei’s works “明月松间照, 清泉石上 流'. It is quite reasonable to imagine that Snyder had learned from these images in ancient Chinese poems and further developed them in his own writings. His practice is similar to what many Chinese translators and poets do in the New Culture Movement of China at the beginning of the 20th century. They translated and learned from the new style poems of western cultures so as to reconstruct the traditional Chinese culture. Here, the development of western culture and eastern culture seem to have a surprising similarity.

\section{CONCLUSION}

From the above discussion and analysis on Snyder's translation of ancient Chinese poems we can have such an idea that Snyder's practice is a combination of social demand and his personal affection for Chinese culture. Just like those Chinese scholars in the New Culture Movement, Snyder looked for new religious support and new aesthetic values in Chinese culture so as to reconstruct the traditional western cultures, which he believed had stepped into a wrong direction. Such kind of translation practice may bring about some criticism as it may be regarded as exploitation to the source culture. However, it does contribute a lot to popularizing the source culture in the target culture and in turn promotes the communication between different countries and different cultures in the world.

\section{REFERENCES}

[1] Charles Frazier. (1997). Cold Mountain. New York: Grove Press.

[2] Jack Kerouac. (1958). The Dharma Bums (Penguin Modern Classics). London: Penguin Books.

[3] Leed, Jacob. (1986). "Gary Snyder: Unpublished Preface.” Journal of Modern Literature 13.1, 177-180.

[4] McNeil, Katherine. (1983). Gary Snyder: A Bibliography. New York: The Phoenix Bookshop.

[5] Parkinson, Thomas. (1984). The Poetry of Gray Snyder. Sagetrieb 3.1(Spring): 49-61.

[6] Peter Stambler. (1996). Encounters With Cold Mountain: Poems by Han Shan. Beijing: Panda Books.

Ying Wu was born in Zhenjiang, China in 1979. She received his M.A. degree in Translation Study from Nanjing University, China in 2009.

She is currently a lecturer in the English Department of Zhenjiang Watercraft College of PLA, Zhenjiang, China. Her research interests include Translation and Foreign Language Teaching.

Qi Pan was born in Zhenjiang, China in 1987. She received her B.A. degree in English language and literature from Jiangsu University of Science and Technology, China in 2009.

She is currently a tutor in English Department, Zhenjiang Watercraft College of PLA, Zhenjiang, China. Her research interests include Linguistics and Foreign Language Teaching. 